\title{
Effects of dietary forage sources on rumen microbial protein synthesis and milk performance in early lactating dairy cows
}

\author{
W. Zhu, ${ }^{*}$ Y. Fu, ${ }^{*}$ B. Wang, ${ }^{*}$ C. Wang, ${ }^{*} \dagger$ J. A. Ye,${ }^{*}$ Y. M. Wu, ${ }^{* 1}$ and J.-X. Liu ${ }^{* 1}$ \\ *Institute of Dairy Science, Zhejiang University, Hangzhou 310058, P.R. China \\ †Zhejiang A and F University, Hangzhou 311300, P.R. China
}

\begin{abstract}
The objective of this study was to evaluate the effects of dietary forage sources on milk performance, rumen microbial protein synthesis, and $\mathrm{N}$ utilization in early lactation dairy cows. Twelve primiparous Chinese Holstein dairy cows $(45 \pm 6.0 \mathrm{DIM})$ were used in a $3 \times 3$ Latin square design. Diets were isonitrogenous and isocaloric, with a forage-to-concentrate ratio of 45:55 [dry matter (DM) basis] and contained similar concentrate mixtures. Different forage sources were then added (on a DM basis): $21 \%$ corn silage, $19 \%$ corn stover, and $5 \%$ alfalfa hay (CS); $19 \%$ corn silage, $21 \%$ Chinese wild rye hay and $5 \%$ alfalfa hay (CWR); or $19 \%$ corn silage, $9 \%$ Chinese wild rye hay, and $17 \%$ alfalfa hay $(\mathrm{AH})$. Each period lasted for $21 \mathrm{~d}$, with the first $14 \mathrm{~d}$ for an adaptation period. Dry matter intake was not affected by the source of dietary forage. Milk yield was higher for cows fed $\mathrm{AH}$ than those fed CS, with an intermediate value for CWR. Milk protein content was higher in the cows fed AH compared with CWR (3.02 vs. 2.92\%), with CS $(2.95 \%)$ at an intermediate position. The contents of milk fat and lactose were not different among the treatments. However, milk efficiency (milk yield/DM intake) was higher for cows fed AH than those fed CS, with those fed CWR intermediate. Cows fed AH had higher microbial protein yield and metabolizable protein than those fed CS or CWR. The concentrations of urea $\mathrm{N}$ in the urine, blood, and milk were decreased for cows fed $\mathrm{AH}$, indicating an increased $\mathrm{N}$ conversion. The results indicated that corn stover could replace Chinese wild rye grass in the diets for lactating cows and that a high proportion of alfalfa hay in the diet is beneficial for milk protein production by increasing microbial protein yield. This can be attributed to the improving the supply of rumen-available energy.
\end{abstract}

Key words: forage, microbial protein, lactation

Received May 21, 2012.

Accepted November 3, 2012.

${ }^{1}$ Corresponding authors: ymwu@zju.edu.cn and liujx@zju.edu.cn

\section{INTRODUCTION}

Forage comprises half or more of the diet of dairy cows, affecting the DMI and thereby affecting the energy intake (Kendall et al., 2009). With the development of herbivorous animals, the gap between forage supply and demand is increasing by $10 \%$ annually in China (Li and Wan, 2005). High-quality forages such as alfalfa hay for dairy cows is especially in short supply in China. In $2010,230 \times 10^{6} \mathrm{~kg}$ of alfalfa hay had been imported from foreign countries, mainly from the United States, whereas only $100 \times 10^{6} \mathrm{~kg}$ was produced domestically (Wang, 2011). At the same time, it is estimated that more than $100 \times 10^{9} \mathrm{~kg}$ of corn stover is generated annually in China (Pang et al., 2008), and most of it is not reasonably utilized. Chinese wild rye grass hay has been extensively included in ruminant diets (Yang et al., 2009).

Contents of CP, NDF, and NFC are different among these forage sources. Compared with corn stover and Chinese wild rye grass, alfalfa hay is higher in contents of CP, RDP, and RUP (Zhao and Li, 2009). Alfalfa hay contains a higher NFC content, thus providing more energy available for the capture of RDP in the rumen compared with corn stover and Chinese wild rye grass. Increasing RUP by $1 \%$ can improve milk production by $1 \mathrm{~kg}$ (NRC, 2001). Providing both RDP and RUP may meet the requirement for MP, whereas the increasing MP supply can increase not only milk yield but also milk protein yield (Wright et al., 1998). In a previous study, a strong correlation was observed between dietary MP content and 4\% FCM yield or milk protein yield (Wang et al., 2007).

It is a strategic policy for the Chinese dairy industry to make full use of crop residues such as corn stover to meet the demand of forage and reduce the dependence on imported alfalfa hay. However, no study has been conducted to compare the effects of substituting corn stover or Chinese wild rye grass for alfalfa hay as a forage source for dairy cows. Because of low CP and energy contents in corn stover and Chinese wild rye grass, protein and energy supplementation is needed to meet the requirements for lactation. Therefore, the objective 
of this study was to investigate the effect of these forage sources on the lactation performance, microbial protein (MCP) synthesis, and $\mathrm{N}$ utilization efficiency in early lactation dairy cows fed isonitrogenous and isocaloric diets.

\section{MATERIALS AND METHODS}

\section{Animals and Experimental Design}

The use of animals was approved by the Animal Care Committee of Zhejiang University (Hangzhou, China). Twelve primiparous Chinese Holstein cows (552 \pm 16.0 $\mathrm{kg}$ BW; $45 \pm 6.0$ DIM) were separated into 3 groups and randomly allocated to 1 of 3 dietary treatments in a $3 \times 3$ Latin square design. Groups were balanced for DIM and milk yield.

The experimental diets (Table 1) had a forage-toconcentrate ratio of 45:55 (DM basis), with a similar component of concentrate but with different forage sources as follows: (1) TMR containing corn stover (CS), (2) TMR containing Chinese wild rye grass (CWR), or (3) TMR containing alfalfa hay (AH). All the diets were isonitrogenous and isocaloric and formulated to meet the $\mathrm{NE}_{\mathrm{L}}$ requirements of cows for milk production of $30 \mathrm{~kg} / \mathrm{d}$ (Ministry of Agriculture of P.R. China, 2004). Feed was offered ad libitum to allow for at least 5 to $10 \%$ orts.

Each experimental period consisted of $14 \mathrm{~d}$ for adaptation, followed by $7 \mathrm{~d}$ for sample collection. The cows were housed in a tiestall barn and fed and milked 3 times daily at 0600,1330 , and $2000 \mathrm{~h}$. All of the cows had free access to drinking water throughout the experiment.

\section{Sampling Collection and Measurements}

The feed offered and refused was weighed for 3 consecutive days on $\mathrm{d} 17,18$, and 19 of each period to determine the DMI. Ort samples for each cow were collected in proportion to the wet weight for each day. The forages and concentrates were sampled weekly to determine the DM content. Daily feed and ort samples were pooled by treatment, period, and cow, and then the subsample was used for chemical analysis. Samples were dried in a forced-air oven at $60^{\circ} \mathrm{C}$ for $48 \mathrm{~h}$ and stored in sealed plastic containers at $-20^{\circ} \mathrm{C}$ until analyses. Dried samples were ground through a 2-mm screen in a Wiley mill (Arthur H. Thomas Co., Philadelphia, PA) and then through a 1-mm screen in a Cyclotec mill (Tecator 1093; Tecator AB, Höganäs, Sweden) before analysis. The contents of DM, OM, ash, NPN, soluble $\mathrm{CP}$, and total $\mathrm{N}$ of the ingredients, orts, and feces were determined according to the procedures of the Association of Official Analytical Chemists (AOAC, 1990). Starch was detected using a colorimetric method (Bertrand et al., 2003). The NDF, lignin, NDIN, and ADIN were analyzed by the method of Van Soest et al. (1991). Diet compositions that were calculated according to the chemical analysis and inclusion rate of ingredients are presented in Table 2. At the beginning and end of each period, cows were weighed one by one on a weighing scale before morning feeding to calculate the change in BW.

Table 1. Ingredients of the experimental diets

\begin{tabular}{|c|c|c|c|}
\hline \multirow[b]{2}{*}{ Item $(\%$ of $\mathrm{DM})$} & \multicolumn{3}{|c|}{ Treatment $^{1}$} \\
\hline & CS & CWR & $\mathrm{AH}$ \\
\hline Corn silage & 21.0 & 19.0 & 19.0 \\
\hline Chinese wild rye grass hay & 0.00 & 21.0 & 9.00 \\
\hline Corn stover & 19.0 & 0.00 & 0.00 \\
\hline Alfalfa hay & 5.00 & 5.00 & 17.0 \\
\hline Ground corn grain & 28.0 & 26.6 & 28.0 \\
\hline Soybean meal, $46.3 \%$ CP & 13.0 & 12.0 & 10.0 \\
\hline Cottonseed meal & 3.50 & 3.50 & 3.50 \\
\hline Wheat bran & 0.00 & 3.00 & 4.00 \\
\hline $\mathrm{DDGS}^{2}$ & 6.00 & 6.00 & 6.00 \\
\hline Dicalcium phosphate & 1.20 & 0.85 & 0.75 \\
\hline Limestone & 0.75 & 0.80 & 0.50 \\
\hline Sodium bicarbonate & 0.75 & 0.75 & 0.75 \\
\hline Salt & 0.50 & 0.50 & 0.50 \\
\hline Premix ${ }^{3}$ & 1.00 & 1.00 & 1.00 \\
\hline Ca salts of long-chain FA & 0.30 & 0.00 & 0.00 \\
\hline
\end{tabular}


Table 2. Chemical composition of the experimental diets ${ }^{1}$

\begin{tabular}{lccc}
\hline & \multicolumn{3}{c}{ Treatment $^{2}$} \\
\cline { 2 - 4 } Composition & CS & CWR & AH \\
\hline CP $(\%$ of DM) & 16.2 & 16.1 & 16.3 \\
Soluble CP (\% of CP) & 38.8 & 38.7 & 39.4 \\
NPN (\% of SCP) & 24.4 & 24.2 & 26.5 \\
NDIN (\% of CP) & 11.3 & 12.9 & 13.8 \\
ADIN (\% of CP) & 5.30 & 5.70 & 6.40 \\
NDF (\% of DM) & 36.4 & 36.0 & 33.0 \\
NFC $(\%$ of DM) & 35.2 & 35.9 & 38.7 \\
Lignin $\left(\%\right.$ of DM) $_{\text {Sucrose (\% of DM) }}$ & 6.00 & 6.20 & 6.10 \\
Starch (\% of DM) & 7.60 & 8.80 & 9.60 \\
Ca ${ }^{4}(\%$ of DM) & 23.5 & 22.9 & 0.76 \\
$\mathrm{P}^{4}(\%$ of DM) & 0.85 & 0.59 & 0.78 \\
$\mathrm{NE}_{\mathrm{L}}^{4}(\mathrm{Mcal} / \mathrm{kg}$ of DM) & 0.58 & 1.59 & 1.61 \\
\hline
\end{tabular}

${ }^{1}$ Compositions of experimental diets were calculated according to the chemical analysis and inclusion rate of ingredients as indicated in Table 1. Chemical compositions of the main forages are as follows: corn stover $(\%$ of DM): $84.4 \% \mathrm{OM}, 6.5 \% \mathrm{CP}, 66.5 \% \mathrm{NDF}$, and $36.2 \% \mathrm{ADF}$; Chinese wild rye grass hay (\% of DM): $88.6 \%$ $\mathrm{OM}, 7.7 \% \mathrm{CP}, 67.5 \% \mathrm{NDF}$, and $35.2 \% \mathrm{ADF}$; and alfalfa hay (\% of DM): $89.0 \% \mathrm{OM}, 16.9 \% \mathrm{CP}, 39.4 \% \mathrm{NDF}$, and $30.6 \% \mathrm{ADF}$.

${ }^{2} \mathrm{CS}=\mathrm{TMR}$ containing corn stover as the main forage; $\mathrm{CWR}=\mathrm{TMR}$ containing Chinese wild rye grass as the main forage $\mathrm{AH}=\mathrm{TMR}$ containing alfalfa hay as the main forage.

${ }^{3}$ Calculated as $100-(\% \mathrm{NDF}+\% \mathrm{CP}+\%$ ether extract $+\%$ ash $)$.

${ }^{4}$ Calculated based on Ministry of Agriculture of P.R. China (2004).

Cows were milked at 0630, 1430, and $2130 \mathrm{~h}$ daily. The milk production was recorded and milk samples were collected on d 17, 18, and 19 of each period using milk-sampling devices (Waikato Milking Systems NZ Ltd., Waikato, Hamilton, New Zealand). Two 50-mL aliquots of the milk samples were collected daily at each milking and pooled in a proportion of 4:3:3. One subsample with added Bromopol (milk preservative; D \& F Control Systems Inc., San Ramon, CA) was stored at $4^{\circ} \mathrm{C}$ for later analysis of the protein, fat, and lactose by infrared analysis (Laporte and Paquin, 1999) using a spectrophotometer (Fossomatic 4000; Foss Electric A/S, Hillerød, Denmark). The subsample without Bromopol was stored at $-20^{\circ} \mathrm{C}$ for the analysis of MUN, according to the diacetyl monoxime-binding method described by Wang et al. (2010).

Blood samples $(10 \mathrm{~mL})$ were collected from the coccygeal vein of each cow into heparinized test tubes at approximately $3 \mathrm{~h}$ after feeding on d 20 of each period. The sample was then centrifuged at $3,000 \times g$ for 15 min to obtain the plasma. All of the plasma samples were stored at $-20^{\circ} \mathrm{C}$ for the later analysis of $\mathrm{BUN}$ according to the procedure described by Wang et al. (2007).

\section{In Situ Digestion in the Rumen}

Three ruminally cannulated Chinese Holstein cows $(604 \pm 36 \mathrm{~kg}$ of BW; $15 \pm 2.4 \mathrm{~kg}$ of milk yield; $213 \pm$ 6.5 DIM) were housed in individual stalls for the deter- mination of the in vitro rumen $\mathrm{OM}$ and $\mathrm{CP}$ degradation of all 3 diets. The ingredients (\% of DM) of the diet for the cannulated cows included $48.5 \%$ concentrate, $16.9 \%$ corn silage, $27.7 \% \mathrm{AH}$, and $6.9 \%$ CWR. The diet was fed 3 times daily for a total intake of $1.5 \%$ of the $\mathrm{BW}$. The samples for the degradation study were dried at $65^{\circ} \mathrm{C}$ and ground through a $3-\mathrm{mm}$ screen in a mill (Arthur H. Thomas Co.). About $5 \mathrm{~g}$ of each sample was placed into a nylon bag $(10 \times 20 \mathrm{~cm} ; 50-\mu \mathrm{m}$ pore size; Ankom Technology Corp., Macedon, NY) in 6 duplicates. The bags were tied to the end of a 40-cm nylon line and attached to a stainless-steel weight, and then placed in the ventral sac of the rumen through ruminal cannula to incubate for $2,4,8,12,16,24,36$, and 48 h. After removal from the rumen, the bags were rinsed thoroughly in cool running tap water until the wash water ran clear. The samples were dried at $65^{\circ} \mathrm{C}$ in an oven and weighed to determine the residue mass and the residues were then pooled by the duration within each cow. The residues and original diet samples were ground to pass through a 1-mm screen in a Cyclotec mill (Tecator 1093; Tecator AB) before analysis of the $\mathrm{DM}, \mathrm{OM}$, and $\mathrm{CP}$. The in situ digestion constants were estimated using the following nonlinear model (Ørskov et al., 1980): $p=a+b[1-\exp (-c t)]$, where $p=$ the rate of disappearance at time $t(\mathrm{~h}), a=$ the rapidly degradable fraction in the rumen, and $b=$ the fraction slowly degraded at rate $c(c>0)$. The effective degradability $(\mathbf{d g})$ was calculated by assuming a passage rate $(\boldsymbol{k p})$ of $8 \% / \mathrm{h}$ (Madsen and Hvelplund, 1985), using the 
formula of Ørskov et al. (1980): $\mathrm{dg}=a+b c /(c+k p)$, where $a, b, c$, and $k p$ are the constants described above.

\section{Estimation of MCP Yield and MP}

Urinary purine derivatives were used to estimate the MCP yield in the rumen (Chen and Gomes, 1992). Spot urine samples during the lactation trial were collected twice daily at approximately 6 and $12 \mathrm{~h}$ after feeding on d 17, 18, and 19 of each period. The daily urine samples were pooled by cow and $20-\mathrm{mL}$ subsamples were acidified immediately with $80 \mathrm{~mL}$ of $0.036 \mathrm{~mol}$ of $\mathrm{H}_{2} \mathrm{SO}_{4} / \mathrm{L}$ and stored at $-20^{\circ} \mathrm{C}$ for later analysis. At the end of the trial, all of the urine samples were thawed at $25^{\circ} \mathrm{C}$ and filtered through Whatman no. 1 filter paper (Broderick et al., 2008). The filtrates were then analyzed for urea $\mathrm{N}$ using the colorimetric method (Rahmatullah and Boyde, 1980). The purine derivatives were analyzed by the procedure of Chen and Gomes (1992) and creatinine was analyzed using a picric acid assay (Oser, 1965). Creatinine has been validated as a marker to estimate urine volume (Leonardi et al., 2003) and was assumed to be excreted at a rate of $29 \mathrm{mg} / \mathrm{kg}$ of BW for calculating the urine volume excretion rate (Valadares et al., 1999).

The MP was estimated as the sum of the intestinally absorbable dietary protein (IADP) and intestinally absorbable MCP (IAMCP). The IADP was estimated by the equation: IADP $=$ RUP $\times \mathrm{CP}$ intake $\times \mathrm{IDP}$, where IDP is the intestinal digestibility of RUP, determined from the residue of feedstuff incubated in the rumen for $16 \mathrm{~h}$, according to a modified 3-step procedure (Gargallo et al., 2006). The IAMCP was estimated by the equation: $\mathrm{IAMCP}=\mathrm{MCP} \times 0.64(\mathrm{NRC}, 2001)$.

\section{Statistical Analysis}

Statistical analyses were carried out using SAS software (SAS Institute, 2000). Data within each treatment group were checked for normality using PROC UNIVARIATE NORMAL. Intake of DM, milk yield and composition, milk efficiency, MCP yield, MUN, and urinary $\mathrm{N}$ were analyzed as a multiple Latin square using PROC MIXED with covariance type AR (1). For lactation performance, DMI, milk efficiency, MCP yield, MUN, and urinary N, the statistical model included square, period, treatment, day, and treatment $\times$ period interaction, with the square, treatment, day, and their interactions as the fixed effects and the cow within the treatment as the random effect. For BW gain and BUN, the statistical model included the square, period, treatment, and treatment $\times$ period interaction, with the square, treatment, and their interactions as the fixed effects and the cow within the treatment as the random effect. The square $\times$ treatment interactions were originally evaluated but were removed from the final statistical models because they were not significant for any of the variables. Results were reported as LSMEANS and the differences between the treatments were detected using the Tukey adjustment.

Data on the constants of the OM and CP degradation in the rumen $(a, b$, and $c), \mathrm{dg}, \mathrm{RUP}$, and intestinal digestion parameters were analyzed using PROC GLM of SAS (SAS Institute, 2000). For the regression analysis, the REG procedure was used to evaluate the MP and microbial protein yield relative to the milk protein yield. A statistically significant difference was defined at $P<0.05$ and trends were declared at $0.05 \leq P \leq$ 0.10 .

\section{RESULTS}

\section{Feed Intake, Milk Yield, and Composition}

The milk yield and composition are presented in Table 3. Daily DMI did not differ $(P=0.30)$ among the treatments, with an average of $17.6 \mathrm{~kg} / \mathrm{d}$. The milk yield was higher for cows fed $\mathrm{AH}$ than those fed CS $(P=0.07)$, resulting in a higher milk efficiency (milk yield/DMI) for AH than for CS $(P=0.01)$ with an intermediate value for CWR. The milk protein content was also higher for the cows fed AH compared with those fed CWR ( $P=0.01 ; 3.02$ vs. $2.92 \%)$, with no difference between the CWR and CS values. The contents of milk fat $(P=0.12)$ and milk lactose $(P=0.17)$ did not show differences among the treatments. The BW gain was similar among the diets $(P=0.45)$.

\section{In Situ Digestion in the Rumen}

The results for the rumen degradation of the $\mathrm{OM}$ and CP are presented in Table 4. For the OM degradation, AH had higher $a(P=0.01), b(P<0.01)$, and $c$ values $(P<0.01)$; thus, the dg value of $\mathrm{OM}$ for $\mathrm{AH}$ was higher $(P=0.01)$ compared with CS and CWR (53.2 vs. 47.8 and $47.8 \%$ ). The $a$ and $c$ values for CP degradation were similar among the treatments, whereas CS exhibited a lower $(P=0.01) b$ value than $\mathrm{AH}$ and CWR. The dg value of $\mathrm{CP}$ for $\mathrm{AH}$ was higher $(P=0.01)$ than that for CS, with no difference between CS and CWR. The RUP for AH was lower $(P=0.04)$ than that for $\mathrm{CS}$, with no difference between CWR and $\mathrm{AH}$ or CS (Table 4).

\section{MCP Yield and MP}

The MCP yield for AH was $17.2 \%$ higher than that for CS $(P=0.01$; Table 5) and $15.3 \%$ higher than for 
Table 5. Effects of corn stover, Chinese wild rye grass, and alfalfa hay as dietary forage sources on the microbial protein (MCP) yield, $\mathrm{N}$ utilization efficiency, and urea $\mathrm{N}$ concentration in the blood, urine, and milk

\begin{tabular}{lcccc}
\hline & \multicolumn{3}{c}{ Treatment $^{1}$} & \\
\cline { 2 - 4 } Item & $\mathrm{CS}$ & $\mathrm{CWR}$ & $\mathrm{AH}$ & SEM \\
\hline $\mathrm{MCP}^{2}(\mathrm{~g} / \mathrm{d})$ & $1,601^{\mathrm{b}}$ & $1,627^{\mathrm{b}}$ & $1,876^{\mathrm{a}}$ & 62.6 \\
$\mathrm{~N}$ conversion & $0.258^{\mathrm{b}}$ & $0.266^{\mathrm{b}}$ & $0.291^{\mathrm{a}}$ & 0.0066 \\
Urea N concentration $(\mathrm{mg} / \mathrm{dL})$ & & & $10.0^{\mathrm{b}}$ & 0.40 \\
Blood & $11.0^{\mathrm{a}}$ & $12.0^{\mathrm{a}}$ & $287^{\mathrm{b}}$ & 15.6 \\
Urine & $346^{\mathrm{a}}$ & $327^{\mathrm{ab}}$ & $11.0^{\mathrm{b}}$ & 0.10 \\
Milk & $12.0^{\mathrm{a}}$ & $12.0^{\mathrm{a}}$ & \\
\hline
\end{tabular}

${ }^{\mathrm{a}, \mathrm{b}}$ Means within a row with different superscripts differ $(P<0.05)$.

${ }^{1} \mathrm{CS}=\mathrm{TMR}$ containing corn stover as the main forage; CWR $=$ TMR containing Chinese wild rye grass as the main forage; $\mathrm{AH}=\mathrm{TMR}$ containing alfalfa hay as the main forage.

${ }^{2}$ Estimated based on the purine derivatives (Chen and Gomes, 1992).

${ }^{3} \mathrm{~N}$ conversion $=$ milk protein yield $/ \mathrm{CP}$ intake

yield (Stern and Hoover, 1979; Lascano and Heinrichs, 2011). Compared with CS and CWR, AH had higher OM degradation (Table 4), resulting from higher $a$ and $c$ values (though a lower $b$ ). Higher $a$ and $c$ values were largely attributable to the greater NFC content (Table 2 ). On the other hand, the higher MCP synthesis in $\mathrm{AH}$ should be attributed to increased supply of the rumenfermentable energy and RDP compared with CS and CWR. The RUP content was lower in AH than in the CS (Table 4), but the IADP was not different between $\mathrm{AH}$ and CS. Therefore, the higher MP from AH was attributed to the higher MCP (Table 6).

Milk protein secretion in dairy cows is closely associated with the supply of MP (NRC, 2001), which consists of the IADP and IAMCP. A significant relationship existed between the MP and milk protein yield (Figure $1 \mathrm{~A})$. Our results indicated that the higher MCP yield in the cows fed AH contributed to a greater MP supply and, hence, a higher milk protein yield compared with the CS and CWR diets. As little difference existed in concentrate ingredients among the 3 diets to make the diets isonitrogenous and isocaloric, the difference should be mostly based on forage source. Therefore, it is critical to enhance MCP synthesis in the rumen when forage of low quality such as CS is included in the diet for lactating cows.

In dairy cows, the urinary $\mathrm{N}$ (Tamminga, 1992) and BUN (NRC, 2001) arise largely from excess RDP. The excessive ammonia absorbed through the rumen wall into the blood will convert to urea in the liver and urea is excreted in the rumen, urine, and milk (Linn and Olson, 1995). Compared with CS and CWR, the decreased urinary $\mathrm{N}$ and BUN observed under $\mathrm{AH}$ indicated reduced rumen $\mathrm{N}$ losses and improved ammonia utilization, resulting in higher MCP yield for $\mathrm{AH}$ than those for CS and CWR. High concentrations of BUN in lactating dairy cows may alter uterine $\mathrm{pH}$ for several days after estrus (Rhoads et al., 2004) and decrease embryo viability (Rhoads et al., 2006). These parameters were not measured in the current study,

Table 6. Effects of corn stover, Chinese wild rye grass, and alfalfa hay as dietary forage sources on the intestinal $\mathrm{N}$ digestibility of the dietary protein and the MP supply to the cows

\begin{tabular}{lcccc}
\hline & \multicolumn{3}{c}{ Treatment $^{1}$} \\
\cline { 2 - 4 } Item & CS & CWR & AH & SEM \\
\hline $\operatorname{IDP}^{2}(\%$ of RUP $)$ & 64.1 & 67.6 & 71.3 & 2.53 \\
$\operatorname{IADP}^{3}(\mathrm{~g} / \mathrm{d})$ & 912 & 915 & 929 & 14.0 \\
$\operatorname{IAMCP}^{4}(\mathrm{~g} / \mathrm{d})$ & $1,024^{\mathrm{b}}$ & $1,041^{\mathrm{b}}$ & $1,201^{\mathrm{a}}$ & 40.0 \\
$\operatorname{MP}^{5}(\mathrm{~g} / \mathrm{d})$ & $1,936^{\mathrm{b}}$ & $1,956^{\mathrm{b}}$ & $2,130^{\mathrm{a}}$ & 41.3 \\
\hline
\end{tabular}

a,b Means within a row with different superscripts differ $(P<0.05)$.

${ }^{1} \mathrm{CS}=\mathrm{TMR}$ containing corn stover as the main forage; CWR $=$ TMR containing Chinese wild rye grass as the main forage; $\mathrm{AH}=\mathrm{TMR}$ containing alfalfa hay as the main forage.

${ }^{2} \mathrm{IDP}=$ measured intestinal digestibility of RUP. The feedstuff incubated in the rumen for $16 \mathrm{~h}$ was used to determine the IDP according to a modified 3-step procedure (Gargallo et al., 2006).

${ }^{3} \mathrm{IADP}=$ intestinally absorbable dietary protein $=\mathrm{RUP} \times \mathrm{CP}$ intake $\times$ IDP.

${ }^{4} \mathrm{IAMCP}=$ intestinally absorbable microbial protein $(\mathrm{MCP})=\mathrm{MCP} \times 0.64(\mathrm{NRC}, 2001)$.

${ }^{5} \mathrm{MP}=\mathrm{IAMCP}+\mathrm{IADP}$. 

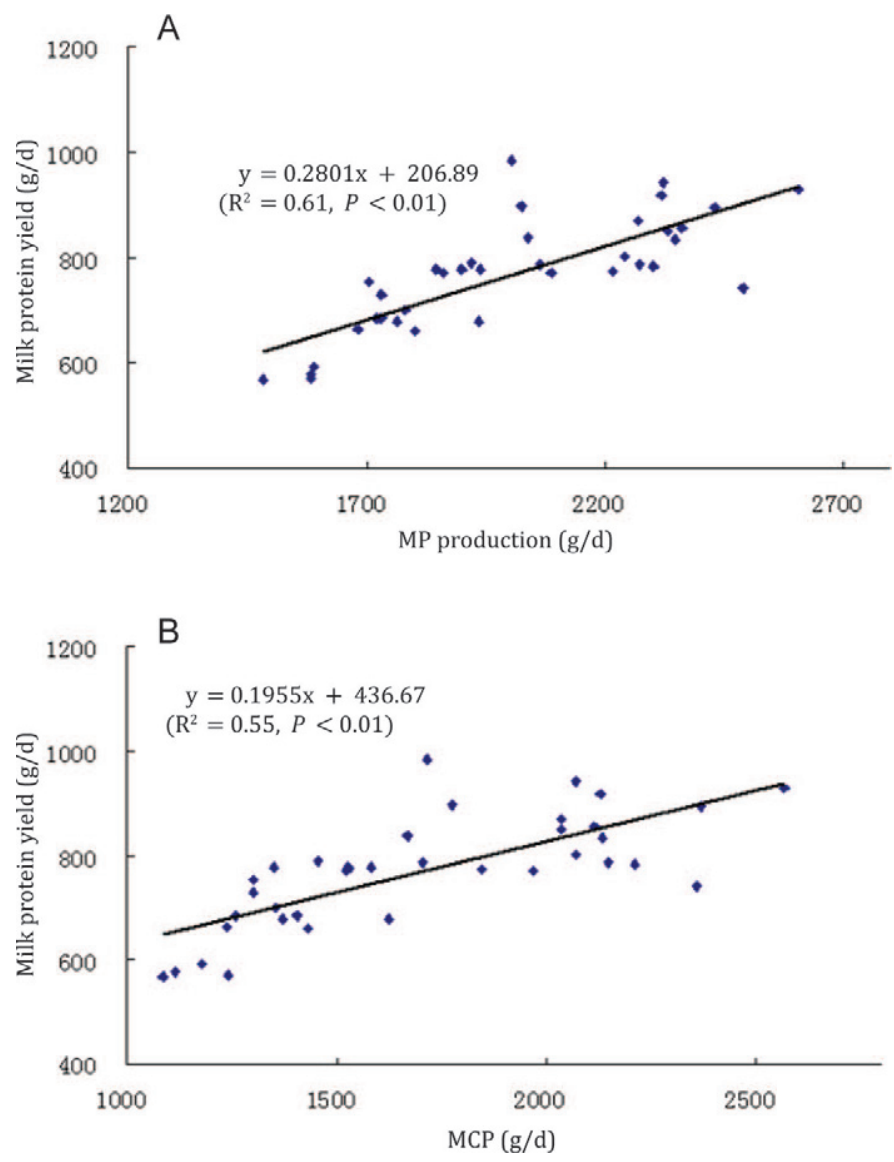

Figure 1. Regressions of the milk protein yield on the MP (A) and microbial protein (MCP) yield (B) in lactating cows. Color version available in the online PDF.

but the reduced BUN in the cows fed $\mathrm{AH}$ would benefit reproduction. A reduction in urinary $\mathrm{N}$ excretion was also observed when the MCP yield was increased (Broderick et al., 2008). Most of urinary $\mathrm{N}$ is excreted as urea, which can be rapidly hydrolyzed to ammonia and volatilized into the atmosphere (Broderick, 2003). Therefore, replacing CS or CWR with AH may help reduce the environmental burden of Chinese dairy production and improve animal health.

Another major source of urinary $\mathrm{N}$ is derived from the incomplete conversion of absorbed AA into productive uses such as milk protein and tissue production (Tamminga, 1992). In the current study, the urea in urine and milk with the CS diet was higher than with the $\mathrm{AH}$ diet, whereas the milk protein excretion was much lower. The results indicate that $\mathrm{AH}$ may have had a better AA balance and resulted in more efficient AA utilization for productive uses compared with CS and CWR. Additional work is needed to improve the utilization efficiency of feed resources available locally, such as CS or CWS, through the increased supply of rumen-fermentable energy and improved AA balance.

\section{CONCLUSIONS}

Compared with CS and CWR, the higher degradation of the rumen $\mathrm{OM}$ and the more readily fermentable carbohydrates for $\mathrm{AH}$ provided an increased energy supply for MCP synthesis in the rumen and the greater MP supply resulted in an increased yield of milk protein. The improved $\mathrm{N}$ conversion efficiency with decreased concentrations of urea $\mathrm{N}$ in the urine, plasma, and milk may benefit both animal health and environmental protection. We infer that a sufficient supply of the energy available for MCP synthesis is critical for lactating dairy cows fed forage of low quality, such as CS and CWR.

\section{ACKNOWLEDGMENTS}

This research was supported by grants from the National Basic Research Program of the China Ministry of Science and Technology (Beijing, China; grant no. 2011CB100801) and from the China Agriculture Research System (CARS-37). The authors gratefully thank all of the staff of the Hangzhou Zhengxing Animal Industry Company (Hangzhou, China) for their assistance in the feeding, milking, and care of the animals. We also acknowledge the members of the Institute of Dairy Science at Zhejiang University (Hangzhou, China) for their assistance in the sampling and analysis of the feeds, blood, and urine.

\section{REFERENCES}

AOAC (Association of Official Analytical Chemists). 1990. Official Methods of Analysis. Vol. 1. 15th ed. AOAC, Arlington, VA.

Bertrand, A., Y. Castonguay, P. Nadeau, S. Laberge, R. Michaud, G. Bélanger, and P. Rochette. 2003. Oxygen deficiency affects carbohydrate reserves in overwintering forage crops. J. Exp. Bot. $54: 1721-1730$.

Broderick, G. A. 2003. Effects of varying dietary protein and energy levels on the production of lactating dairy cows. J. Dairy Sci. 86:1370-1381.

Broderick, G. A., N. D. Luchini, S. M. Reynal, G. A. Varga, and V. A. Ishler. 2008. Effect on production of replacing dietary starch with sucrose in lactating dairy cows. J. Dairy Sci. 91:4801-4810.

Chen, X. B., and M. J. Gomes. 1992. Estimation of microbial protein supply to sheep and cattle based on urinary excretion of purine derivatives: An overview of technical details. Int. Feed Res. Unit, Occasional Publ. Rowett Research Institute, Aberdeen, UK.

Clark, J. H., T. H. Klusmeyer, and M. R. Cameron. 1992. Microbial protein synthesis and flows of nitrogen fractions to the duodenum of dairy cows. J. Dairy Sci. 75:2304-2323.

Gargallo, S., S. Calsamiglia, and A. Ferret. 2006. Technical note: A modified three-step in vitro procedure to determine intestinal digestion of proteins. J. Anim. Sci. 84:2163-2167.

Kendall, C., C. Leonardi, P. C. Hoffman, and D. K. Combs. 2009. Intake and milk production of cows fed diets that differed in dietary neutral detergent fiber and neutral detergent fiber digestibility. J. Dairy Sci. 92:313-323.

Khorasani, G. R., E. K. Okine, and J. J. Kennelly. 2001. Effects of forage source and amount of concentrate on rumen and intestinal digestion of nutrients in late-lactation cows. J. Dairy Sci. $84: 1156-1165$. 
Laporte, M.-F., and P. Paquin. 1999. Near-infrared analysis of fat, protein, and casein in cow's milk. J. Agric. Food Chem. 47:26002605.

Lascano, G. J., and A. J. Heinrichs. 2011. Effects of feeding different levels of dietary fiber through the addition of corn stover on nutrient utilization of dairy heifer precision-fed high and low concentrate diets. J. Dairy Sci. 94:3025-3036.

Leonardi, C., M. Stevenson, and L. E. Armentano. 2003. Effect of two levels of crude protein and methionine supplementation on performance of dairy cows. J. Dairy Sci. 86:4033-4042.

Li, X. L., and L. Q. Wan. 2005. Research progress on Medicago sativa silage technology. Acta Prataculturae Sinica 14:9-15.

Linn, J. G., and J. D. Olson. 1995. Using milk urea nitrogen to evaluate diets and reproductive performance of dairy cattle. Pages 155-167 in 4-State Appl. Nutr. Manag. Conf., La Crosse, WI. University of Wisconsin, Madison.

Madsen, J., and T. Hvelplund. 1985. Protein degradation in the rumen. A comparison between in vivo, nylon bag, in vitro and buffer measurements. Acta Agric. Scand. 25(Suppl.):103.

Ministry of Agriculture of P.R. China. 2004. Feeding Standard of Dairy Cattle (NY/T 34-2004). Ministry of Agriculture of P.R. China, Beijing, China.

Nocek, J. E., and J. B. Russell. 1988. Protein and energy as an integrated system: Relationship of ruminal protein and carbohydrate availability to microbial synthesis and milk production. J. Dairy Sci. 71:2070-2107.

NRC. 2001. Nutrient Requirements of Dairy Cattle. 7th rev. ed. Natl. Acad. Sci., Washington, DC.

Ørskov, E. R., F. D. D. Hovell, and F. Mould. 1980. The use of the nylon bag technique for the evaluation of feedstuffs. Trop. Anim. Prod. 5:195-213.

Oser, B. L. 1965. Hawk's Physiological Chemistry. 14th ed. McGrawHill, New York, NY.

Pang, Y. Z., Y. P. Liu, X. J. Li, K. S. Wang, and H. R. Yuan. 2008. Improving biodegradability and biogas production of corn stover through sodium hydroxide solid state pretreatment. Energy Fuels $22: 2761-2766$

Rahmatullah, M., and T. R. Boyde. 1980. Improvements in the determination of urea using diacetyl monoxime; methods with and without deproteinisation. Clin. Chim. Acta 107:3-9.

Rhoads, M. L., R. O. Gilbert, M. C. Lucy, and W. R. Butler. 2004. Effects of urea infusion on the uterine luminal environment of dairy cows. J. Dairy Sci. 87:2896-2901.

Rhoads, M. L., R. P. Rhoads, R. O. Gilbert, R. Toole, and W. R. Butler. 2006. Detrimental effects of high plasma urea nitrogen levels on viability of embryos from lactating dairy cows. Anim. Reprod. Sci. $91: 1-10$

SAS Institute. 2000. SAS User's Guide: Statistics. Version 8.01. SAS Inst. Inc., Cary, NC.

Stern, M. D., and W. H. Hoover. 1979. Methods for determining and factors affecting rumen microbial protein synthesis: A review. J. Anim. Sci. 49:1590-1603.

Tamminga, S. 1992. Nutrition management of dairy cows as a contribution to pollution control. J. Dairy Sci. 75:345-357.

Valadares, R. F. D., G. A. Broderick, S. C. Valadares Filho, and M. K. Clayton. 1999. Effect of replacing alfalfa silage with high moisture corn on ruminal protein synthesis estimated from excretion of total purine derivatives. J. Dairy Sci. 82:2686-2696.

Van Soest, P. J., J. B. Robertson, and B. A. Lewis. 1991. Methods for dietary fiber, neutral detergent fiber, and nonstarch polysaccharides in relation to animal nutrition. J. Dairy Sci. 74:3583-3597.

Voelker Linton, J. A., and M. S. Allen. 2009. Nutrient demand interacts with forage family to affect nitrogen digestion and utilization responses in dairy cows. J. Dairy Sci. 92:1594-1602.

Wang, C., H. Y. Liu, Y. M. Wang, Z. Q. Yang, J. X. Liu, Y. M. Wu, T. Yan, and H. W. Ye. 2010. Effects of dietary supplementation of methionine and lysine on milk production and nitrogen utilization in dairy cows . J. Dairy Sci. 93:3661-3670.

Wang, C., J. X. Liu, Z. P. Yuan, Y. M. Wu, S. W. Zhai, and H. W. Ye. 2007. Effect of level of metabolizable protein on milk production and nitrogen utilization in lactating dairy cows. J. Dairy Sci 90:2960-2965.

Wang, J. Q. 2011. Five key indicators leading the direction of China dairy industry. China Anim. Husbandry Vet. Med. 38:5-9.

Wright, T. C., S. Moscardini, P. H. Luimes, P. Susmel, and B. W McBride. 1998. Effects of rumen-undegradable protein and feed intake on nitrogen balance and milk protein production in dairy cows. J. Dairy Sci. 81:784-793.

Yang, H. J., Q. Yue, Y. C. Cao, D. F. Zhang, and J. Q. Wang. 2009 Effects of crude feruloyl and acetyl esterase solutions of Neocallimastix sp. YQ1 and Anaeromyces sp. YQ3 isolated from Holstein steers on hydrolysis of Chinese wildrye grass hay, wheat bran, maize bran, wheat straw and corn stalks. Anim. Feed Sci. Technol. 154:218-227.

Zhao, T. Z., and H. Y. Li. 2009. Study on ruminal degradation of mainly protein and fiber sources in dairy diets. Contemp. Anim. Husb. 11:29-32. 